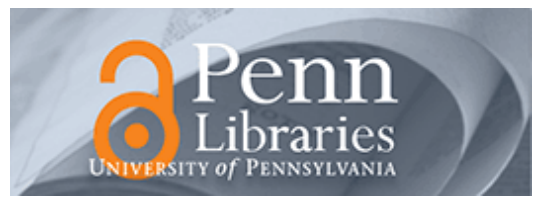

University of Pennsylvania ScholarlyCommons

\title{
How I Became an Encyclopedia Editor-and Other Tales of a Wayward Scholar
}

Nancy H. Hornberger

University of Pennsylvania, nancyh@gse.upenn.edu

Follow this and additional works at: https://repository.upenn.edu/gse_pubs

Part of the Applied Linguistics Commons, Curriculum and Instruction Commons, Educational Assessment, Evaluation, and Research Commons, and the Instructional Media Design Commons

\section{Recommended Citation}

Hornberger, N. H. (2011). How I Became an Encyclopedia Editor-and Other Tales of a Wayward Scholar. Modern Language Journal, 95 (4), 633-634. http://dx.doi.org/10.1111/j.1540-4781.2011.01248_4.x

This paper is posted at ScholarlyCommons. https://repository.upenn.edu/gse_pubs/309

For more information, please contact repository@pobox.upenn.edu. 
How I Became an Encyclopedia Editor-and Other Tales of a Wayward Scholar Disciplines

Applied Linguistics | Curriculum and Instruction | Education | Educational Assessment, Evaluation, and Research | Instructional Media Design 
Hornberger, N. (2011). How I became an Encyclopedia editor -- and other tales of a wayward scholar. Modern Language Journal, 95(4), 633-635.

http://dx.doi.org/10.1111/j.1540-4781.2011.01248_4.x

How I became an Encyclopedia editor - and other tales of a wayward scholar NANCY H. HORNBERGER, The University of Pennsylvania

How did I come to edit the Encyclopedia of Language and Education (Springer 2008)? It happened by increments, over time, and with heavy reliance on personal relationships. In retrospect, adequate time and the right people are for me the sine qua non of a successful encyclopedia project - whether success is measured in terms of contributors' satisfaction, publishers' market indicators, or overall use and appreciation of the work (as of 2010, the Encyclopedia was Springer's most downloaded ebook in the Humanities, Social Sciences and Law, with over 33,000 tracked downloads each in 2008 and 2009). Scholarly expertise in the field is certainly a fundamental prerequisite; but as with any scholarly writing, there are good and bad exemplars, thorough and thoughtful encyclopedia chapters, and shoddy ones. There are many contributing factors to the quality of knowledge produced and disseminated in such an undertaking, but I am convinced that without generous timelines and suitable intervals for serious scholarly review, thinking and writing, and especially without committed people - scholars and publishers - willing to go beyond the call of duty (particularly since deans, provosts and review committees are increasingly, and mistakenly in my view, not counting these publications toward tenure), a truly comprehensive state-of-the-art publication can never happen.

Marie Sheldon, senior editor with Kluwer (later Springer), first approached me in 
early 2002 to explore the possibility of my serving as general editor for a second edition of David Corson's (1998) highly successful Encyclopedia of Language and Education, for which I had co-edited the volume on Research Methods. I was hesitant, for reasons of both my available time and my deference to Corson's impressive work, especially in the wake of his untimely passing in 2001. Marie was patient, gently insistent, and ultimately persuasive over the ensuing two years in convincing me that I was the person for the job, the publisher's and other volume editors' first choice; and that she and the publisher would work with me to facilitate the work in every way possible, a promise which turned out to be largely true, although I also believed - and believe to this day - that most publishers really have no idea how much scholarly work is involved in editing or even contributing to an encyclopedia or handbook. As an illustration: I made a decision early on in this undertaking that I would answer every Encyclopedia-related email on the same day it came in, a decision I am convinced made all the difference in keeping the project moving, but which also took over my life for $4+$ years once the actual preparation, editing, and production of the ten volumes was under way.

But I get ahead of my story. Marie, with editorial forbearance and exceptional publishing skills, was the first of a network of extraordinary personal relationships that became the building blocks for the Encyclopedia, side by side with the conceptual work of defining a field in ten volumes of 20-30 chapters each. Once I had signed on in December 2003, we soon added my Ph.D. student Francis Hult as assistant (for whom the publisher provided a year-long stipend), an editorial advisory board, volume co-editors, and hundreds of scholars who agreed to contribute. In retrospect, I was calling on a network of personal collegial relationships built up over a career, headed by a superb 
group of volume co-editors: Stephen May (volume 1), Brian Street (2), Marilyn MartinJones and Anne-Marie de Mejía (3), Nelleke van Deusen-Scholl (4), Jim Cummins (5), Jasone Cenoz (6), Elana Shohamy (7), Patricia Duff (8), Angela Creese and Peter Martin (9), and Kendall King (10). It was amidst the ready acceptance of these top-notch and generous colleagues to take on the volume editor roles and, in the process of working with them, to define the conceptual terrain for the volumes and volume chapters, that my motivation to do this, to do it well, and to make it a worthy sequel to Corson's first edition, really took off.

I began to see it as an opportunity to build on the first edition, not only by updating and adding to the coverage of topics in the field, but by increasing the representation of scholarly voices from non-English speaking and non-Western parts of the world and, equally, reaching an expanded worldwide audience of scholars, students, teachers, educational administrators, and policymakers. Both aims were eventually realized to at least some degree, the first facilitated not only by the vast international and interdisciplinary collegial networks my volume editors and I drew on but also by use of electronic communication and online submission systems that were not available for the first edition - we ultimately included contributions from all continents and 41 countries across the globe. The second aim was enabled by Springer's generosity in making the Encyclopedia available not just through hard copy sets sold to libraries and later also paperback singles, but especially by widespread electronic access through libraries, through each and every contributor's full access to the whole Encyclopedia, and through specific outreach to scholars and libraries in the global south (as of 2010, at least half of the ebook usage was coming from Africa, Asia-Pacific, and Latin America). 
Yes, there were editorial constraints, but here again time and relationships carried the day. For example, I had opted to keep the chapter format David Corson had adopted for the first edition, with chapters organized around thematic headings: early developments, major contributions, work in progress, problems and difficulties, and future directions. For some authors and topics, these headings worked more readily than for others, but the volume editors and I found that, by lending our time, expertise, and personal interest in working individually with authors on interpreting these headings, they were able to accommodate them. The result is, I believe, more conducive to readers' ability to consult, compare, and compile across chapters and volumes.

Another constraint arose late in the publishing process, during the copyediting stage, when I was dismayed to find, in addition to the usual dose of copyediting errors, very strange word splices appearing at the end of nearly every line of text, rendering an unacceptable final product for such a carefully written and edited work. Rather than overrule my concern, Marie responded by arranging for a multiparty phone call involving, as I recall, the publisher (her boss) in Germany, copyeditors in two different cities in India, Marie and her assistant in Boston, and me in Philadelphia. We spent at least an hour on the phone working out the source of the problem, across languages and varieties, software and writing traditions, until we were able to arrive at a way forward that met both my concern for a finely edited work and the publishers' concern to keep as closely as possible to the production timeline. Again, Marie rose to the occasion by devoting her own and her assistant's time to going over the whole text in search of the offending splices. My point here is that it was the personal relationship she and I had built over time and her willingness to extend herself that enabled a satisfactory outcome. 
Like many of my colleagues in applied linguistics, I have written (too) many encyclopedia and handbook chapters and have been invited to author at least twice as many more that I have declined; I have likewise been approached by publishers to edit other encyclopedias, handbooks, and readers, some of which I have declined and some accepted. Despite my very positive experience with the Encyclopedia of Language and Education, I am wary of the overabundance and unevenness in quality of such summative publications. The competitive publishing world is both boon and bane to the production and dissemination of scholarly knowledge through these formats. Certainly, we can be grateful for the more comprehensive and accessible encyclopedic publications, but it is also in the nature of the market for publishers to put forth new, updated, and competing editions at (too) frequent intervals. It is up to us as scholars to remain the judges of just how many state-of-the-art chapters we can write on how many different topics and how often - whether at 5-, 10-, or 20-year intervals. After all, if we spend all our time reviewing literature and writing comprehensive statements, when do we do the creative and field-shaping research on which such statements depend?

\section{REFERENCE}

Corson, D. (1997). Encyclopedia of language and education. Dordrecht, The Netherlands: Kluwer. 